\title{
Abietane Diterpenes from Hyptis platanifolia
}

\author{
Edigênia C. C. Araújo ${ }^{a}$, Mary Anne S. Lima $^{a}$, Edson P. Nunes ${ }^{b}$ and Edilberto R. Silveira $^{*, a}$ \\ ${ }^{a}$ Curso de Pós-Graduação em Química Orgânica, Departamento de Química Orgânica e \\ Inorgânica and ${ }^{b}$ Departamento de Biologia, Centro de Ciências, Universidade Federal do Ceará, \\ CP 12200, 60971-270 Fortaleza-CE, Brazil
}

\begin{abstract}
Das raízes de Hyptis platanifolia foram isolados três novos diterpenos abietanos 19-oxoinuroyleanol, 11,14-di-hidroxi-12-metoxi-7-oxo-8,11,13-abietatrien-19,20 $\beta$-olídeo and 19,20-epoxi12-metoxi-11,14,19-tri-hidroxi-7-oxo-8,11,13-abietatrieno, em adição ao inuroyleanol e a coulterona. Investigação das partes aéreas forneceu a mistura de esteróides estigmasterol e $\beta$-sitosterol, e os triterpenos ácido betulínico e ácido ursólico. A caracterização estrutural dos compostos foi estabelecida com base em métodos espectroscópicos, principalmente RMN uni e bidimensional, e comparação com dados da literatura.
\end{abstract}

Three new abietane diterpenes 19-oxo-inuroyleanol, 11,14-dihydroxy-12-methoxy-7-oxo8,11,13-abietatrien-19,20ß-olide and 19,20-epoxy-12-methoxy-11,14,19-trihydroxy-7-oxo-8,11,13abietatriene, in addition to inuroyleanol, and coulterone were isolated from roots of Hyptis platanifolia. Investigation of the aerial parts yielded a mixture of the steroids stigmasterol and $\beta$-sitosterol, and the triterpenes betulinic and ursolic acids. Structural characterization of all compounds was established on the basis of spectroscopic methods, particularly 1D and 2D NMR, and comparison with data from literature.

Keywords: Hyptis platanifolia, NMR, abietane diterpenes, betulinic and ursolic acids, steroids

\section{Introduction}

The genus Hyptis (Labiatae) is large (300 species) and widespread in the tropical America. ${ }^{1}$ Several species have been reported to possess medicinal properties and are frequently reported in the treatment of gastrointestinal infections, as antifungal, antibacterial, anticonvulsant, to alleviate cramps and pain, as well as in the treatment of malaria. ${ }^{2-7}$ Despite their reported use for medicinal purposes, a literature survey revealed that the phytochemical analysis of plants belonging to the Hyptis genus have been limited to a few species.

During the course of previous work on Brazilian Hyptis species, we have reported the isolation and cytotoxic activity of abietane diterpenoids from roots of Hyptis martiusii. ${ }^{8}$ In continuation to the investigation of plants from this genus, we present now the phytochemical study of Hyptis platanifolia Mart. ex Benth, a small shrub that grows in abundance in the Northeast of Brazil. From the roots extract three new abietane diterpenoids were isolated 1-3, in addition to the known diterpenes

*e-mail: edil@ufc.br inuroyleanol 4 and coulterone 5. ${ }^{9}$ From the aerial parts the triterpenes betulinic 6 and ursolic acids $7^{10}$ and a mixture of the steroids stigmasterol $\mathbf{8}$ and $\beta$-sitosterol 9, ${ }^{11}$ were characterized.

\section{Results and Discussion}

Compound 1 was isolated as an orange solid, mp 147$150{ }^{\circ} \mathrm{C}$. The IR spectrum revealed bands for hydroxyl (3341 $\mathrm{cm}^{-1}$ ), and two carbonyl functions related to an aldehyde $\left(1727,2721 \mathrm{~cm}^{-1}\right)$ and a conjugated ketone $\left(1619 \mathrm{~cm}^{-1}\right)$. The ${ }^{1} \mathrm{H}$ NMR spectrum (Table 1) showed two deshielded signals assignable to a hydrogen-bonded hydroxyl group at $\delta 13.30$ and an aldehyde proton at $\delta 9.26$, corroborating with the observations from the IR. The presence of an isopropyl group attached to the aromatic ring indicative of an abietane-type diterpenoid, ${ }^{12}$ was suggested by the presence of the characteristic signals at $\delta 3.32$ (sept, $J 7.1$ $\mathrm{Hz}, \mathrm{H}-15), 1.41$ (d, J 7.1Hz, H-16) and $1.40(\mathrm{~d}, J 7.1 \mathrm{~Hz}, \mathrm{H}-$ 17). In addition, three methyl singlets at $\delta 3.82\left(\mathrm{OCH}_{3}-\right.$ 12), $1.43(\mathrm{H}-20)$ and $1.23(\mathrm{H}-18)$ were assigned to one methoxyl and two methyls attached to quaternary carbons, 
Table 1. ${ }^{1} \mathrm{H}$ and ${ }^{13} \mathrm{C}$ NMR data assignments for the compound $1\left(\mathrm{CDCl}_{3}, 500 / 125 \mathrm{MHz}\right)$

\begin{tabular}{|c|c|c|c|c|}
\hline \multirow[t]{2}{*}{ Carbon } & \multicolumn{2}{|c|}{ HMQC correlations } & \multicolumn{2}{|c|}{ HMBC correlations } \\
\hline & $\delta{ }^{13} \mathrm{C}$ & $\delta{ }^{1} \mathrm{H}$ & ${ }^{2} J(\mathrm{C}, \mathrm{H})$ & ${ }^{3} J(\mathrm{C}, \mathrm{H})$ \\
\hline 1 & 35.9 & $\begin{array}{c}3.38(\mathrm{dt}, J 10.9,2.3 \mathrm{~Hz}) \\
1.51(\mathrm{~m})\end{array}$ & & \\
\hline 2 & 17.9 & $\begin{array}{l}1.83(\mathrm{~m}) \\
1.77(\mathrm{~m})\end{array}$ & & \\
\hline 3 & 32.3 & $\begin{array}{l}1.53(\mathrm{~m}) \\
1.42(\mathrm{~m})\end{array}$ & & \\
\hline 4 & 49.8 & & & \\
\hline 5 & 42.3 & $2.40(\mathrm{dd}, J 14.7,2.5 \mathrm{~Hz})$ & C-4, C-10 & C-18, C-19, C-20 \\
\hline 6 & 37.8 & $\begin{array}{l}2.73(\mathrm{dd}, J 14.7,17.1 \mathrm{~Hz}) \\
2.14(\mathrm{dd}, J 17.1,2.5 \mathrm{~Hz})\end{array}$ & $\mathrm{C}-5, \mathrm{C}-7$ & C- -10 \\
\hline 7 & 204.5 & & & \\
\hline 8 & 112.7 & & & \\
\hline 9 & 134.1 & & & \\
\hline 10 & 39.4 & & & \\
\hline 11 & 139.1 & & & \\
\hline 12 & 152.7 & & & \\
\hline 13 & 127.1 & & & \\
\hline 14 & 159.0 & & & \\
\hline 15 & 26.5 & $3.32($ sept $)$ & C-13, C-16, C-17 & $\mathrm{C}-12, \mathrm{C}-14$ \\
\hline 16 & 20.7 & $1.41(\mathrm{~d}, J 7.1 \mathrm{~Hz})$ & $\mathrm{C}-15$ & C-17 \\
\hline 17 & 20.6 & $1.40(\mathrm{~d}, J 7.1 \mathrm{~Hz})$ & C- 15 & C-16 \\
\hline 18 & 14.6 & $1.23(\mathrm{~s})$ & $\mathrm{C}-4$ & $\mathrm{C}-3, \mathrm{C}-5, \mathrm{C}-18$ \\
\hline 19 & 205.0 & $9.26(\mathrm{~s})$ & $\mathrm{C}-4$ & $\mathrm{C}-3, \mathrm{C}-5, \mathrm{C}-18$ \\
\hline 20 & 18.7 & $1.43(\mathrm{~s})$ & C- 10 & $\mathrm{C}-1, \mathrm{C}-5, \mathrm{C}-9$ \\
\hline $\mathrm{OCH}_{3}$ & 62.5 & $3.82(\mathrm{~s})$ & & C- 12 \\
\hline $\mathrm{OH}^{3}$ & & 5.76 (br s) & $\mathrm{C}-11$ & C-9, C-12 \\
\hline $\mathrm{OH}$ & & $13.30(\mathrm{~s})$ & C-14 & C- $8, C-13$ \\
\hline
\end{tabular}

respectively. Signals relative to an $\mathrm{ABC}$ system at $\delta 2.73$ (dd, $J 14.7$ and $17.1 \mathrm{~Hz}, \mathrm{H}-6_{\mathrm{eq}}$ ), 2.14 (dd, $J 2.5$ and $17.1 \mathrm{~Hz}$, $\mathrm{H}-6_{\mathrm{ax}}$ ) and 2.40 (dd, $J 2.5$ and $14.7 \mathrm{~Hz}, \mathrm{H}-5$ ) were also observed and confirmed by analysis of the ${ }^{1} \mathrm{H}-{ }^{1} \mathrm{H}$ COSY experiments. The magnitude of the coupling constant of $17.1 \mathrm{~Hz}$ observed to the methylene group at $\delta 2.73$ (dd, $J$ 17.1 and $14.7 \mathrm{~Hz}, \mathrm{H}-6_{\mathrm{eq}}$ ) and 2.14 (dd, $J 17.1$ and $2.5 \mathrm{~Hz}$, H- $\left.6_{\mathrm{ax}}\right)$ was attributed to the geminal coupling of a methylene " $\alpha$ " to a ketone group, coupling just with a hydrogen at $\delta 2.40(\mathrm{dd}, J 14.7$ and $2.5 \mathrm{~Hz}, \mathrm{H}-5){ }^{9}$ Furthermore, geminal couplings between the methylene hydrogens at $\delta 3.38\left(\mathrm{dt}, J 2.3\right.$ and $\left.10.9 \mathrm{~Hz}, \mathrm{H}-1_{\mathrm{eq}}\right)$ and 1.51 ( $\left.\mathrm{m}, \mathrm{H}-1_{\mathrm{ax}}\right) ; \delta 1.83\left(\mathrm{~m}, \mathrm{H}-2_{\mathrm{eq}}\right.$ ) and $1.77\left(\mathrm{~m}, \mathrm{H}-2_{\mathrm{ax}}\right.$ ); and $\delta 1.53$ $\left(\mathrm{m}, \mathrm{H}-3_{\mathrm{eq}}\right)$ and $1.42\left(\mathrm{~m}, \mathrm{H}-3_{\mathrm{ax}}\right)$, besides vicinal couplings for the hydrogens at $\delta 1.83$ and $1.77\left(\mathrm{H}-2_{\mathrm{eq}}\right.$ and $\left.\mathrm{H}-2_{\mathrm{ax}}\right)$ with both methylene at $\delta 3.38$ and $1.51\left(\mathrm{H}-1_{\text {ax }}\right.$ and $\left.\mathrm{H}-1_{\mathrm{eq}}\right)$ and at $\delta 1.53$ and $1.42\left(\mathrm{H}-3_{\text {eq }}\right.$ and $\left.\mathrm{H}-3_{\text {ax }}\right)$, revealed one subsystem constituted by six protons belonging to three adjacent methylene groups, which were placed between two quaternary $\mathrm{sp}^{3}$ carbon atoms.

Comparative analysis of $\mathrm{BB}$ and DEPT $-{ }^{13} \mathrm{C}$ NMR spectra (Table 1) revealed 21 lines, in agreement with the $\mathrm{C}_{21} \mathrm{H}_{28} \mathrm{O}_{5}$ suggested molecular formula from the EIMS data $\left(\mathrm{m} / 2\left[\mathrm{M}^{\circ+}\right] 360\right)$. From this analysis, one can easily deduce the presence of two carbonyls ( $\delta 205.0$ and 204.5), one of which of an aldehyde, five $\mathrm{sp}^{3}$ methyl carbons (one methoxyl and four non functionalized methyls), four methylenes, two methine, and eight non-protonated carbons, six of which were unsaturated.

The substitution pattern of the fully substituted C aromatic ring was established from the HMBC analysis (Table 1). The suggestion of the location of one hydroxyl group at C-11 was determined by correlations of the $\mathrm{OH}$ hydrogen at $\delta 5.76(\mathrm{br} \mathrm{s})$ with the carbons at $\delta 152.7$ (C$\left.12,{ }^{3} J\right), 139.1\left(\mathrm{C}-11,{ }^{2} J\right)$ and $134.1\left(\mathrm{C}-9,{ }^{3} J\right)$. The deshielded resonance of one hydrogen at $\delta 3.38$ of the methylene group at $\mathrm{C}-1$, allowed its assignment to the

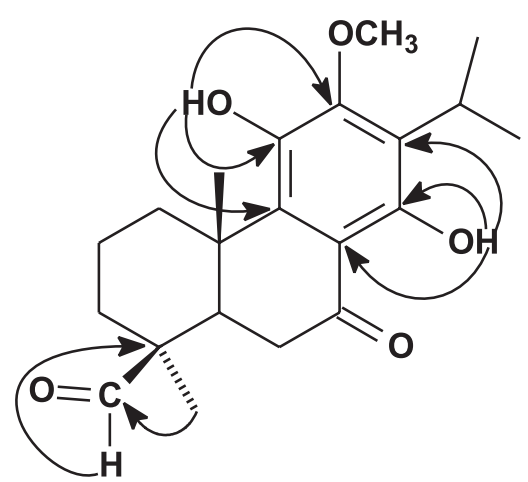

Figure 1. Key HMBC correlations observed for the19-oxoinuroyleanol (1). 
$\mathrm{C}-1 \beta$ equatorial hydrogen as already observed for abietane derivatives having a $\mathrm{C}-11$ phenol group on ring C..$^{13}$ Long-range correlations between the chelated hydroxyl group at $\delta 13.30$ with the carbons at $\delta 159.0$ $\left(\mathrm{C}-14,{ }^{2} \mathrm{~J}\right), 127.1\left(\mathrm{C}-13,{ }^{3}\right)$ and $112.7\left(\mathrm{C}-8,{ }^{3} \mathrm{~J}\right)$, and of the methoxyl group at $\delta 3.82$ with the carbon at $\delta 152.7$ (C$\left.12,{ }^{3} \mathrm{~J}\right)$, determined the position of hydroxyl and methoxyl groups at C-14 and C-12, respectively. Moreover, the correlation of the hydrogen of the formyl group at $\delta 9.26(\mathrm{H}-19)$ with the quaternary carbon at $\delta$ $49.8\left(\mathrm{C}-4,{ }^{2} J\right)$, and the concomitant correlations of both hydrogens at $\delta 2.40\left(\mathrm{H}-5,{ }^{3} \mathrm{~J}\right)$ and $1.23\left(\mathrm{CH}_{3}-18,{ }^{3} \mathrm{~J}\right)$ with the carbonyl at $\delta 205.0$ (C-19) established that the aldehyde group was, therefore, attached to C-4. (Figure 1). The equatorial orientation of the aldehyde group at C-4, was based on the chemical shift of the aldehyde hydrogen at the $\delta 9.26$ in the ${ }^{1} \mathrm{H}$ NMR, whereas an axial substitution would take that hydrogen to an usual proton range, lower than $\delta 9.7$, in agreement with a previous report by Bohlmann et al. ${ }^{14}$ The above information and comparison of the ${ }^{13} \mathrm{C}$ NMR data found to compound $\mathbf{1}$ with to those published for inuroyleanol 4 and 20-oxo-inuroyleanol 10, isolated from Salvia coulteri (Labiatae), ${ }^{9}$ allowed to establish its structure as the new abietane diterpene 19-oxo-inuroyleanol.

Compound 2 was obtained as an yellow solid with $\mathrm{mp}$ 248-250 ${ }^{\circ} \mathrm{C}$. The molecular formula $\mathrm{C}_{21} \mathrm{H}_{26} \mathrm{O}_{6}$ was established by EIMS $\left(\mathrm{m} / \mathrm{z}\left[\mathbf{M}^{+}\right]\right.$374). The IR spectrum showed the presence of hydroxyls $\left(3351 \mathrm{~cm}^{-1}\right)$ and two carbonyl groups relative to an ester $\left(1735 \mathrm{~cm}^{-1}\right)$ and a conjugated ketone $\left(1618 \mathrm{~cm}^{-1}\right)$. Analysis in the ${ }^{13} \mathrm{C}$ NMR spectrum of $\mathbf{2}$ were similar to those observed for compound 1 (Table 2), except for the absence of the signals relative to the aldehyde and a methyl carbon and the presence of an extra oxygenated methylene at $\delta$ 72.8. The ${ }^{1} \mathrm{H}$ NMR

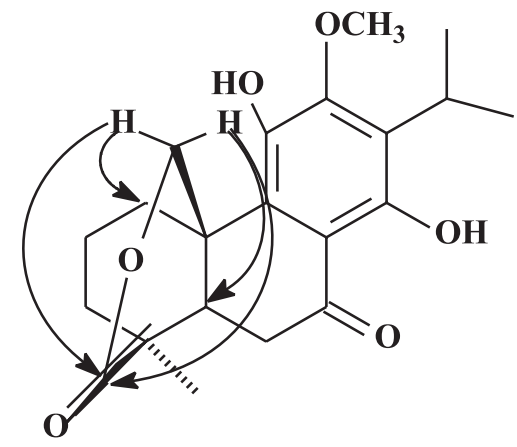

Figure 2. Key HMBC correlations observed for the 11,14dihydroxy-12-methoxy-7-oxo-8,11,13-abietatrien-19,20-olide (2).

spectrum corroborated with these observations, through the absence of the singlets relative to both methyl and aldehyde hydrogens, besides the presence of additional signals for an AB system at $\delta 5.03$ (d, $J 12.5, \mathrm{H}-20$ pro-S) and 4.59 (dd, $J$ $12.5,2.0 \mathrm{~Hz}, \mathrm{H}-20$, pro-R). Significant long-range correlations in the HMBC spectrum were observed between the hydrogen of the $\mathrm{AB}$ system at $\delta 5.03(\mathrm{H}-20$ pro-S) with the carbons at $\delta 175.6\left(\mathrm{C}-19,{ }^{3} \mathrm{~J}\right), 46.7\left(\mathrm{C}-5,{ }^{3} \mathrm{~J}\right)$ and $33.8(\mathrm{C}-$ $\left.10,{ }^{2} J\right)$, while the other at $\delta 4.59(\mathrm{H}-20$ pro-R) showed correlations with the carbons at $\delta 175.6\left(\mathrm{C}-19,{ }^{3} \mathrm{~J}\right), 35.1(\mathrm{C}-$ $\left.1,{ }^{3} J\right)$ and $33.8\left(\mathrm{C}-10,{ }^{2} J\right)$ (Figure 2). The above spectral informations suggested the presence of a $\delta$-lactone moiety for compound 2, with the ring closure through the oxygen between C-19 and C-20. The relative stereochemistry was defined by the small value of the coupling constant $(J 2.0$ $\mathrm{Hz}$ ) observed for the B part of the $\mathrm{AB}$ system at $\delta 4.59$, that was ascribed to the long range coupling between the H-20 pro-S with the hydrogen $\mathrm{H}-1 \alpha$, only possible in structures where the ethereal oxygen C-19 and C-20 is oriented towards $\mathrm{C}-2 .{ }^{15}$ These data suggested the final structure of compound 2 as the new abietane 11,14-dihydroxy-12-methoxy-7-oxo8,11,13-abietatrien-19,20 $\beta$-olide.

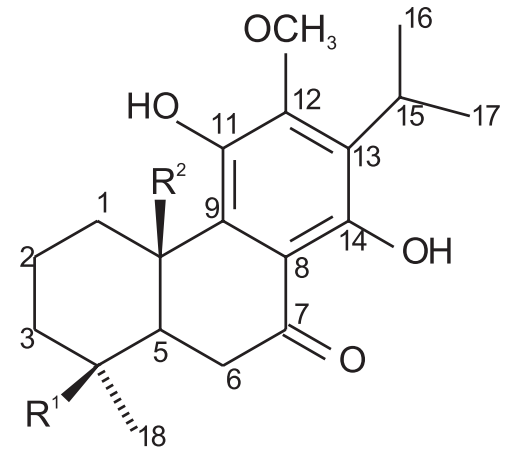

$1 \mathrm{R}^{1}=\mathrm{CHO}, \mathrm{R}^{2}=\mathrm{CH}_{3}$

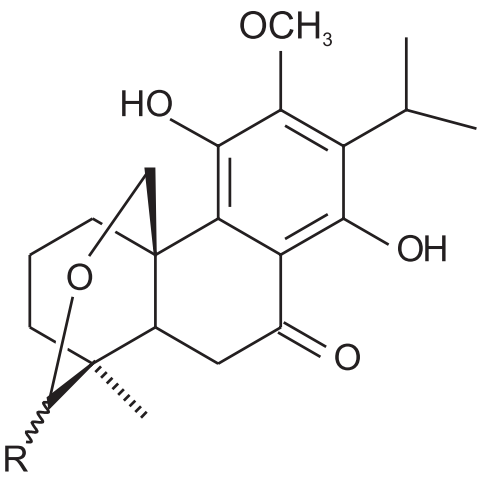

$2 \mathrm{R}=\mathrm{O}$

3a, $3 \mathbf{b} \mathrm{R}=\mathrm{H}, \mathrm{OH}$

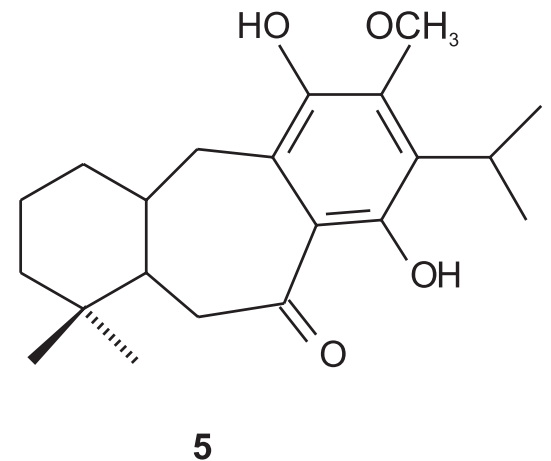

5

$$
\begin{aligned}
4 R^{1} & =R^{2}=C_{3} \\
10 R^{1} & =C_{3}, R^{2}=C H O
\end{aligned}
$$


Compound 3 was obtained as yellow crystals, mp 175.0$181.0^{\circ} \mathrm{C}$. The IR spectrum showed bands relative to hydroxyls $\left(3411 \mathrm{~cm}^{-1}\right)$ and one conjugated carbonyl group $\left(1621 \mathrm{~cm}^{-1}\right)$. The ${ }^{1} \mathrm{H}$ NMR spectrum displayed duplicated signals for the majority of the spin systems with a molar ratio 3:1, what indicated a close relationship with those observed for compound $\mathbf{2}$. A slight difference was found by the presence of extra singlets at $\delta 4.88$ and 4.91 suggesting a diastereoisomeric mixture. The proposition that the $\delta$ lactone moiety of compound $\mathbf{2}$ was reduced on $\mathbf{3}$ was suggested by comparison of their ${ }^{13} \mathrm{C}$ NMR data, since the carbonyl group of $\delta$-lactone of the compound $\mathbf{2}(\delta$ 175.6) was substituted by the hemiaketal methine carbons at $\delta$ 98.4 and 99.2 (C-19) on $\mathbf{3}$, and by the respective ${ }^{3} J$ longrange conectivities in the HMBC spectrum between the $\mathrm{H}$ 19 hemiaketal hydrogens of both epimers at $\delta 4.91$ and 4.88 with the C-5 carbons at $\delta 47.7$ and 44.4 , and C-20 carbons at $\delta 66.4$ and 60.1 , respectively. The stereochemistry at C19 to the two isomers was proposed by the chemical shifts observed for the $\mathrm{AB}$ part of the $\mathrm{ABX}$ systems. The double doublets at $\delta 4.17$ and 4.02 were ascribed to both H-20 pro$\mathrm{S}$ signals. The more deshielded signal at $\delta 4.17$, relative to the most abundant isomer, was related to the compound which contains the hydroxyl group at C-19 in a 1-3 diaxial relationship with the $\mathrm{H}-20$ pro-S, as observed in the structure of the abietane diterpenoid 19-dihydro-deacetyl sesseine 11, also isolated as an diastereoisomeric mixture from Salvia candicans (Labiatae). ${ }^{15}$ Thus, compound $\mathbf{3}$ was determined as the diastereoisomeric mixture of the new diterpene 19,20epoxy-12-methoxy-11,14,19-trihydroxy-7-oxo-8,11,13abietatriene.

Abietane diterpenes are widespread in the Labiatae family, and well represented in the genus Hyptis through the species H. martiusii, ${ }^{8}$ H. suaveolens ${ }^{16}$ and H. dilatata. ${ }^{17}$ On the other hand, icetexane skeletons have been isolated only in the Labiatae genus Salvia, Coleus and Plectranthus. ${ }^{9,15,18}$ The co-occurrence of coulterone $\mathbf{5}$ and inuroyleanol $\mathbf{4}$ in Hyptis martiusii, confirmed the suggestion that icetexane diterpenes has a rearranged abietane skeleton, where the $\mathrm{C}-20 \mathrm{Me}$ group was included in the ring B by migration of the $\mathrm{C}_{9}-\mathrm{C}_{-10}$ bond into the $\mathrm{C}_{9}-\mathrm{C}_{20}$ position, as previously observed by Kelecom in Coleus barbatus. ${ }^{18}$

\section{Experimental}

\section{General procedures}

Melting point were obtained on a Mettler FP82HT and are uncorrected. IR spectra were recorded using a Perkin Elmer 1000 spectrophotometer. Optical rotations were measured on a Perkin Elmer 341 polarimeter. The mass spectra were obtained on a Hewlett-Packard 5971 mass spectrometer by electron impact ionization $(70 \mathrm{eV}) .{ }^{1} \mathrm{H}$ and ${ }^{13} \mathrm{C}$ NMR where recorded on a Bruker Avance DRX500; chemical shifts were given in $\delta$ (ppm) relative to TMS as an internal standard. All compounds were visualized on TLC using the vanillin-sulfuric acid reagent.

\section{Plant material}

Roots and aerial parts of Hyptis platanifolia Mart ex Benth were collected in september 2002, at the flowering stage, from plant populations growing wild in Crato County, Ceará State, Northeast of Brazil. A voucher specimen ( ${ }^{\circ} 31674$ ) has been identified by Dr. Edson Paula Nunes and deposited at the Herbário Prisco Bezerra (EAC), Departamento de Biologia, Universidade Federal do Ceará, Brazil.

\section{Extraction and isolation}

Roots $(2470 \mathrm{~g})$ and aerial parts $(330 \mathrm{~g})$ of $H$. platanifolia were separately pulverized and extracted with hexane at room temperature. The solvent was removed under reduced pressure to give the correspondent extracts. Both residues obtained after hexane extraction were extracted with EtOH.

Chromatography on a Si gel column of the hexane extract from the roots (11.6 g) by elution with hexane, $\mathrm{CHCl}_{3}, \mathrm{EtOAc}$ and $\mathrm{MeOH}$ yielded four fractions. The hexane fraction yielded small crystals, which were collected by removal of the supernatant liquid and recrystallized from $\mathrm{MeOH}$ yielding inuroyleanol 4 (8.0 $\mathrm{mg}$ ). Sucessive flash chromatography of the $\mathrm{CHCl}_{3}$ fraction using $\mathrm{CH}_{2} \mathrm{Cl}_{2}$ :EtOAc as a binary mixture with increasing polarity, yielded compounds $2(17.0 \mathrm{mg})$ and $\mathbf{3}(12.0 \mathrm{mg})$. The EtOH extract $(19.0 \mathrm{~g})$ was submitted to partition with hexane, $\mathrm{CH}_{2} \mathrm{Cl}_{2}$, EtOAc and $\mathrm{MeOH}$ to give four fractions. The $\mathrm{CH}_{2} \mathrm{Cl}_{2}$ fraction $(4.6 \mathrm{~g}$ ) was submitted to the flash chromatography using hexane:EtOAc(90:10) as the isocratic eluting mixture, to afford compound $\mathbf{1}(7.0 \mathrm{mg})$ and coulterone $\mathbf{5}(8.0 \mathrm{mg})$.

The hexane extract of the aerial parts $(2.0 \mathrm{~g})$ was coarsely fractionated on a Silica gel column by elution with hexane, $\mathrm{CHCl}_{3}$ and EtOAc. The $\mathrm{CHCl}_{3}$ fraction was re-chromatographed on Silica gel using hexane, $\mathrm{CHCl}_{3}$ and EtOAc as binary mixtures with increasing polarity, yielding betulinic acid $6(10.0 \mathrm{mg})$ and a mixture of stigmasterol 8 and $\beta$-sitosterol 9 (90.0 mg). Liquid-liquid partition of the EtOH extract (13.5 g) with hexane, $\mathrm{CH}_{2} \mathrm{Cl}_{2}$, EtOAc and $\mathrm{MeOH}$ give four fractions. Successive flash chromatography of the $\mathrm{CH}_{2} \mathrm{Cl}_{2}$ fraction $(5.2 \mathrm{~g}$ ), using 
Table 2. ${ }^{13} \mathrm{C}$ and ${ }^{1} \mathrm{H}$ NMR assignments for compounds $\mathbf{2}$, 3a and $\mathbf{3 b}\left(\mathrm{CDCl}_{3}, 500 / 125 \mathrm{MHz}\right)$

\begin{tabular}{|c|c|c|c|c|c|c|}
\hline \multirow[t]{2}{*}{ Carbon } & \multicolumn{3}{|c|}{${ }^{13} \mathrm{C}$} & \multicolumn{3}{|c|}{${ }^{1} \mathrm{H}$} \\
\hline & 2 & $3 \mathbf{a}$ & $\mathbf{3 b}$ & 2 & $3 \mathbf{a}$ & $3 b$ \\
\hline 1 & 35.1 & 35.1 & 33.8 & $\begin{array}{c}3.61 \\
(\mathrm{dt}, J 13.6 \mathrm{~Hz}) \\
1.48 \\
(\mathrm{ddd}, J 13.6,4.7,2.0 \mathrm{~Hz})\end{array}$ & $\begin{array}{r}3.43(\mathrm{~m}) \\
1.29(\mathrm{~m})\end{array}$ & $\begin{array}{l}3.43(\mathrm{~m}) \\
1.29(\mathrm{~m})\end{array}$ \\
\hline 2 & 21.4 & 22.0 & 21.9 & $\begin{array}{l}1.95(\mathrm{~m}) \\
1.86(\mathrm{~m})\end{array}$ & $\begin{array}{l}2.45(\mathrm{~m}) \\
1.60(\mathrm{~m})\end{array}$ & $\begin{array}{l}2.45(\mathrm{~m}) \\
1.60(\mathrm{~m})\end{array}$ \\
\hline 3 & 40.6 & 39.6 & 37.8 & $\begin{array}{c}2.02(\mathrm{~m}) \\
1.63 \\
(\mathrm{ddd}, J 21.0,13.7,4.3 \mathrm{~Hz})\end{array}$ & $\begin{array}{l}1.63(\mathrm{~m}) \\
1.41(\mathrm{~m})\end{array}$ & $\begin{array}{l}1.63(\mathrm{~m}) \\
1.41(\mathrm{~m})\end{array}$ \\
\hline 4 & 43.1 & 36.6 & 36.8 & & & \\
\hline 5 & 46.7 & 44.4 & 47.7 & $\begin{array}{c}2.22 \\
(\mathrm{dd}, J 16.0,3.4 \mathrm{~Hz})\end{array}$ & $\begin{array}{c}1.90 \\
(\mathrm{dd}, J 15.3,3.0 \mathrm{~Hz})\end{array}$ & $\begin{array}{c}2.15 \\
(\mathrm{dd}, J 15.3,3.0 \mathrm{~Hz})\end{array}$ \\
\hline 6 & 37.1 & 37.8 & 35.2 & $\begin{array}{c}2.84 \\
(\mathrm{dd}, J 16.0,3.4 \mathrm{~Hz}) \\
2.54 \\
(\mathrm{t}, J 16.0 \mathrm{~Hz})\end{array}$ & $\begin{array}{c}3.36(\mathrm{~m}) \\
2.75 \\
(\mathrm{dd}, J 6.3,3.0 \mathrm{~Hz})\end{array}$ & $\begin{array}{c}3.36(\mathrm{~m}) \\
2.75 \\
(\mathrm{dd}, J 6.3,3.0 \mathrm{~Hz})\end{array}$ \\
\hline 7 & 202.4 & 205.7 & 204.4 & & & \\
\hline 8 & 112.4 & 113.5 & 113.4 & & & \\
\hline 9 & 126.5 & 128.6 & 127.7 & & & \\
\hline 10 & 33.8 & 39.3 & 39.4 & & & \\
\hline 11 & 140.4 & 140.3 & 140.4 & & & \\
\hline 12 & 153.0 & 152.4 & 152.8 & & & \\
\hline 13 & 128.6 & 127.5 & 127.7 & & & \\
\hline 14 & 158.9 & 158.2 & 158.3 & & & \\
\hline 15 & 26.6 & 26.5 & 26.5 & $3.33($ sept, $J \quad 7.0 \mathrm{~Hz})$ & $3.31(\mathrm{sept}, J 7.1 \mathrm{~Hz})$ & $3.31(\mathrm{sept}, J 7.1 \mathrm{~Hz})$ \\
\hline 16 & 20.6 & 20.7 & 20.6 & $\begin{array}{c}1.41 \\
(\mathrm{~d}, J 7.0 \mathrm{~Hz})\end{array}$ & $\begin{array}{c}1.38 \\
(\mathrm{~d}, J 7.1 \mathrm{~Hz})\end{array}$ & $\begin{array}{c}1.38 \\
(\mathrm{~d}, J 7.1 \mathrm{~Hz})\end{array}$ \\
\hline 17 & 20.6 & 20.7 & 20.6 & $\begin{array}{c}1.39 \\
(\mathrm{~d}, J 7.0 \mathrm{~Hz})\end{array}$ & $\begin{array}{c}1.37 \\
(\mathrm{~d}, J 7.1 \mathrm{~Hz})\end{array}$ & $\begin{array}{c}1.37 \\
(\mathrm{~d}, J 7.1 \mathrm{~Hz})\end{array}$ \\
\hline 18 & 23.4 & 23.9 & 23.7 & 1.27 & $1.03(\mathrm{~s})$ & $0.97(\mathrm{~s})$ \\
\hline 19 & 175.6 & 99.2 & 98.4 & & $4.88(\mathrm{~s})$ & $4.91(\mathrm{~s})$ \\
\hline 20 & 72.8 & 60.1 & 66.4 & $\begin{array}{c}5.034 .59 \\
(\mathrm{~d}, J 12.5 \mathrm{~Hz}) \\
4.59 \\
(\mathrm{dd}, J 11.6,2.4 \mathrm{~Hz})\end{array}$ & $\begin{array}{c}4.374 .17 \\
(\mathrm{~d}, J 11.6 \mathrm{~Hz}) \\
4.17 \\
(\mathrm{dd}, J 12.5,2.0 \mathrm{~Hz})\end{array}$ & $\begin{array}{c}4.52(\mathrm{~s}) \\
4.02 \\
(\mathrm{dd}, J 11.6,2.4 \mathrm{~Hz})\end{array}$ \\
\hline 21 & 62.7 & 62.5 & 62.5 & $3.82(\mathrm{~s})$ & $3.79(\mathrm{~s})$ & $3.79(\mathrm{~s})$ \\
\hline $\mathrm{OH}$ & & & & $5.81(\mathrm{br} \mathrm{s})$ & $5.74(\mathrm{br} \mathrm{s})$ & $5.74(\mathrm{br} \mathrm{s})$ \\
\hline $\mathrm{OH}$ & & & & $12.96(\mathrm{~s})$ & $13.03(\mathrm{~s})$ & $12.91(\mathrm{~s})$ \\
\hline
\end{tabular}

hexane:EtOAc as a binary mixture with increasing polarity, yielded ursolic acid 7 (66.0 mg).

19-oxo-inuroyleanol, (1). Orange solid. $[\alpha]_{\mathrm{D}}^{20}:+112.0^{\circ}$ $\left(\mathrm{CHCl}_{3} ; c\right.$ 0.09). IR (film) $v_{\max } / \mathrm{cm}^{-1}: 3341,2936,2721$, 1727, 1619, 1493, 1410, 1330, 1243, 1182, 1100, 1060. EIMS m/z (rel. int.): $360\left[\mathrm{M}^{\circ+}\right](100), 345$ (38), 327 (8), 261 (9), 249 (10), 235 (9), 115 (6), 91 (4), 55 (14), 43 (21), 41 (15). ${ }^{1} \mathrm{H}$ and ${ }^{13} \mathrm{C}$ NMR data: see Table 1.

11,14-dihydroxy-12-methoxy-7-oxo-8,11,13abietatrien-19,20-olide, (2). Yellow solid. $[\alpha]_{\mathrm{D}}{ }^{20}+79.0^{\circ}$ $\left(\mathrm{CHCl}_{3} ; c\right.$ 0.1). IR(film) $v_{\max } / \mathrm{cm}^{-1}: 3351,2947,2867,1735$, 1618, 1459, 1417, 1247, 1213, 1131, 1036, 956. EIMS $\mathrm{m} / \mathrm{z}$ (rel. int.): $374\left[\mathrm{M}^{++}\right](100), 359(11), 346(21), 331$ (11), 316 (18), 301 (14), 261 (10), 245 (11), 115 (8), 69 (6), 44 (23), 41 (16). ${ }^{1} \mathrm{H}$ and ${ }^{13} \mathrm{C}$ NMR: see Table 2.

\section{Acknowledgements}

The authors are grateful to CNPq/CAPES/PADCT/ PRONEX/FUNCAP/FINEP for the fellowships and financial support.

\section{References}

1. Harley, R. M.; Reynolds, T.; Advances in the Labiatae Science, The Royal Botanic Gardens: Kew-UK, 1992.

2. Kuhnt, M.; Rimpler, H.; Heinrich, M.; Phytochemistry 1994, 36, 485.

3. Almtorp, G. T.; Hazell, A. C.; Torssel, K. B. G.; Phytochemistry 1991, 30, 2753.

4. Raja Rao, K. V.; Rao, L. J. M.; Rao, N. S. P.; Phytochemistry 1990, 29, 1326. 
5. Asekun, O. T.; Ekundayo, O.; Adevini, B. A.; Fitoterapia 1999, 70, 440.

6. Akah, P. A.; Nwambi, A. I.; Fitoterapia 1993, 62, 42.

7. Pereda-Miranda, R.; Gascon-Figueroa, M.; J. Nat. Prod. 1988, 51, 996.

8. Costa-Lotufo, L. V.; Araújo, E. C. C.; Lima, M. A. S.; Moraes, M. E. A.; Pessoa, C.; Silveira, E. R.; Moraes, M. O.; Pharmazie 2003, 58, 78 .

9. Frontana, B.; Cardenas, J.; Rodriguez-Hahn, L.; Phytochemistry 1994, 36, 739.

10. Ahmad, V. U.; Rhaman-A-U.; Handbook of Natural Products Data-Pentacyclic Triterpenoids, Elsevier: Amsterddam, 1994, vol. 2.

11 Aragão, P. C.; Toledo, J. B.; Morais, A. A.; Braz-Filho, R.; Quim. Nova 1990, 13, 254.
12. Ulubenen. A.; Topcu, G.; Tan, N.; Phytochemistry 1992, 31, 3637.

13. Carreiras, M.C.; Rodriguez, B.; de la Torre, M.C.; Perales, A.; Torres, M.R.; Savona, G.; Piozzi, F.; Tetrahedron 1990, 46, 847.

14. Bohlmann, F.; Suwita, A.; King, R. M.; Robinson, H.; Phytochemistry 1980, 19, 111.

15. Cardenas, J.; Lydia, R.; Phytochemistry 1995, 38, 199.

16. Manchand, P. S.; White, J. D.; Fayos, J.; Clardy, J.; J. Org. Chem. 1974, 39, 2306.

17. Urones, J. G.; Marcos, I. S.; Diez, D.; Cubilla, L. R.; Phytochemistry 1998, 48, 1035.

18. Kelecom, A.; Tetrahedron 1983, 39, 3603.

Received: August 13, 2004 Published on the web: August 24, 2005 